\title{
Multiple forms of esterase in the larvae of Pectinophora gossypiella treated with three volatile oils.
}

\author{
Heba A. Hassan and Sondos A. Mohamed
}

Plant Protection Research Inistitute, A.R.C., Dokki-Giza, Egypt.

\section{ABSTRACT}

In the present work, polyacrylamide gel electrophoresis were used for detection the forms of esterase in the last larval instar of Pectinophora gossypiella. The larvae were treated as newly hatched larvae with sublethal concentration $\left(\mathrm{LC}_{50}\right)$ of three volatile oils (Petroselinum sativum, Coriandrum sativum and Cymbapoyon citratus). The larval tissues showed response towards $\alpha$ - naphthyl acetate and $\beta$ naphthyl acetate substrates. The esterase bands have been classified according to their reaction with three specific inhibitors (Eserine, Chlorphrifos and Fenitrothion).

The results were showed great differences in number of zones of esterase activity and in substrate specificity between treated and untreated samples. Five, four, seven and six esterase bands in untreated and (P. sativum, C. sativum and C. citrates) treated samples respectively, show activity towards $\alpha$ - naphthyl acetate. Six, five, seven and seven esterases were able to hydrolyze $\beta$ - naphthyl acetate in previous samples arrangement. In the case of $\alpha$ - naphthyl acetate, volatile oils caused the increasing of arylestrases and carboxylestrases activities, while cholinesterase activity was inhibited.

Key Words: Pectinophora gossypiella- Esterases- specific inhibitors- electrophoresis

\section{INTRODUCTION}

Esterases exhibit a greater degree of polymorphism than other enzymes because they act on a class of molecules many of which come directly from external environment (Kojima et al., 1970). The esterases can break an ester bond with the help of a water molecule. Most enzymes of this class hydrolyze endogenous substances and are important in intermediary metabolism (Sivakumarm and Maya, 1991), but can also play a role in detoxification of xenobiotics (Shen and Dowd, 1991). Because most insecticides are ester of substituted phosphoric, carbamic, or cyclopropanecarboxylic acids, they are subjected to degradation by esterases (Devonshire, 1991).

These esterases can often be separated into isozymes with different substrate specificities. Also, estreases can be divided as follows; Carboxylestrases inhibited by organophosphorus compounds but not by carbamate (eserine); Cholinesterases inhibited by organophosphorus and carbamate compounds and Arylesterases not inhibited by organophosphorus and carbamate compounds (Augustinsson, 1961).

The pink bollworm, Pectinophora gossypiella is an important cotton pest that causes serious losses in cotton crop due to the attack of the fruitious parts (squares, flowers, green bolls), so the success in controlling such insect is considered to be of great economical importance. Also, for the importance of esterases in physiology, metabolism and xenobiotic detoxification in insects, this study was concerned with characterization and differentiation of $P$. gossypiella esterase activity in untreated and treated larvae with $\mathrm{LC}_{50}$ of three volatile oils (Petroselinum sativum, Coriandrum sativum and Cymbapoyon citratus). 


\section{MATERIAL AND METHODS}

\section{*Insects preparation:}

Pectinophora gossypiella used in this study originated from eggs obtained from a susceptible strain established in the bollworm department, plant protection, Research Institute, Dokki, Giza. This strain was reared in the laboratory on an artificial diet according to (Abdel-Hafez et al., 1982.) under constant laboratory conditions of $26 \pm 1{ }^{\circ} \mathrm{C}$ and $70 \pm 5 \% \mathrm{RH}$.

Glass vials $(2.0 \times 7.5 \mathrm{~cm})$ filled one third with the artificial diet. 60 diet tubes each were used for each concentration $0.5,0.52$ and $0.017 \%\left(\mathrm{LC}_{50}\right.$ values) for Petroselinum sativum, Coriandrum sativum and Cymbapoyon citratus oils, respectively. $0.05 \mathrm{ml}$ for each conc. was applied on the upper surface of the diet/tube/concentration. The same quantity of water was added to the untreated tubes. The tubes were kept uncapping for half an hour then hatched larvae of P. gossypiella were placed individually into each tube using a fine hair brush and coverd with a piece of cotton wool. All the tubes were kept at $26 \pm 1^{\circ} \mathrm{C}$ and $70-75 \%$ R.H. until the larvae reached to last larval instars. Untreated and treated larvae were homogenized, centrifuged and kept frozen.

\section{*Esterases analysis:}

Esterase bands were separated by Polyacrylamide gel electrophoresis (PAGE) according to the method of (Salama et al., 1992).

\section{Substrate and inhibitors studies :}

\section{Reagent :}

- $\quad 0.5 \mathrm{M}$ borat buffer (pH4.1): 30.9 gm boric acid were dissolved in 900ml of distwater and $\mathrm{pH}$ was adjusted using conc. Hcl the final volume was complet up to 1 liter with dist. water.

- $\quad \alpha$ - naphthyl acetate and $\beta$ - naphthyl acetate as substrates.

- Fast blue RR salt (as diazo coupler).

- Stock phosphate buffer (A) 0.1M: 27.8gm sod. dihydrogen phosphate hydrous $\left(\mathrm{NaH}_{2} \mathrm{Po}_{4}-\mathrm{H}_{2} \mathrm{O}\right)$ were dissolved in 1 liter of dist. Water.

- Stock phosphate buffer (B) 0.1M: 53.65 gm disodium hydrogen phosphate $\left(\mathrm{Na}_{2} \mathrm{HPo}_{4}-\mathrm{H}_{2} \mathrm{O}\right)$ was dissolved in 1 liter of dist. water.

- Phosphat buffer (pH6.5): 46ml from mixture (A) and 40ml from mix (B) were mixed and up to one liter of dist. water the $\mathrm{pH}$ was adjusted to 6.5 .

- Destaining: $70 \mathrm{ml}$ of glacial acetic acid was completed to one liter of dist. water.

\section{Procedure:}

After electrophoresis, the gel was soaked in $0.5 \mathrm{M}$ borate buffer $(\mathrm{pH} 4.1)$ for $90 \mathrm{~min}$. at $4{ }^{\mathbf{0}} \mathrm{C}$ (Sims, 1965) to lower the $\mathrm{pH}$ of the gel from 8.8 to $\approx 7$ which the reaction proceeds readily. The low temperature minimizes diffusion of the protein with in the gel. The gel then was rinsed rapidly in two changes of double distilled water.

The gel was stained for esterolytic activity by incubation at $25^{\circ} \mathrm{C}$ in a solution of $100 \mathrm{mg} \alpha$-naphthyl acetate in $2 \mathrm{ml}$ acetone (as substrate) and $100 \mathrm{mg}$ fast blue RR salt in $200 \mathrm{ml}$ of $0.1 \mathrm{M}$ phosphate buffer, pH 6.5 (Sell et al. 1974).

The $\alpha$-naphthyl acetate, which was released on hydrolysis of the substrate, coupled with the dye salt to produce on insoluble pigment at the site of enzyme activity. 
$\beta$ - naphthyl acetate also was used as substrate. After incubation, the gel was destained in $7 \%$ acetic acid.

The effect of esterase inhibitors (Eserine, Chlorphrifos and Fenitrrothion) were examined before the incubation of the substrate and coupler, i.e.; another gel were placed in phosphate buffer containing inhibitor $\left(10^{-4} \mathrm{M}\right)$ for $30 \mathrm{~min}$. at $25^{\circ} \mathrm{C}$ before being incubated with substrate solution. Esterase classification was done according to Augustinsson, (1961) Table (1). The gels were scanned to calculate the relative mobility and concentration of identified bands using Gel-Pro Analyzer.

Table (1): Classification of esterases (Augustinsson, 1961).

\begin{tabular}{|c|c|c|c|}
\hline Inhibitors Enzymes & Eserine & Chlorphrifos & Fenitrrothion \\
\hline Cholinesterases & + & + & + \\
\hline Carboxyestrases & - & + & + \\
\hline \multicolumn{1}{|l|}{ Arylesterases } & - & - & - \\
\hline$(+)=$ Inhibition \\
$(-)=$ Non Inhibition
\end{tabular}

\section{RESULTS}

Esterase isozymes are a group of enzymes characterized by their activity on many ester substrates. The larval tissues of untreated and treated samples of $P$. gossypiella had 18 bands of esterolytic activity capable of hydrolysing $\alpha$-naphthyl acetat and $\beta$ - naphthyl acetate as substrates. The esterase patterns of larval tissues had RF ranged from 0.001 to 0.56 as revealed in Table (2) and Plate $[1(\alpha . n) \& 2(\beta . n)]$.

Table (2): Relative fragmentation $\mathrm{Rf}$ and amount percentage of esterases pattern of $P$. gossypiella larval tissues after treated the $1^{\text {st }}$ instars larvae with Volatile oils detected by $\alpha-\& \beta$-naphthyl acetate.

\begin{tabular}{|c|c|c|c|c|c|c|c|c|c|c|c|c|c|c|c|c|c|}
\hline \multirow{2}{*}{$\begin{array}{l}\text { Band } \\
\text { No. }\end{array}$} & \multirow{2}{*}{$\mathbf{R f}$} & \multicolumn{4}{|c|}{ Control } & \multicolumn{4}{|c|}{ P. sativum } & \multicolumn{4}{|c|}{ C. sativum } & \multicolumn{4}{|c|}{ C. citratus } \\
\hline & & $\alpha$ & $\underset{\%}{\text { Amount }}$ & $\beta$ & $\begin{array}{c}\text { Amount } \\
\%\end{array}$ & $\alpha$ & $\underset{\%}{\text { Amount }}$ & $\beta$ & $\underset{\%}{\text { Amount }}$ & $\alpha$ & $\underset{\%}{\text { Amount }}$ & $\beta$ & $\underset{\%}{\text { Amount }}$ & $\alpha$ & $\underset{\%}{\text { Amount }}$ & $\beta$ & $\underset{\%}{\text { Amount }}$ \\
\hline 1 & 0.001 & - & & + & 3.58 & - & & - & & - & & - & & - & & - & \\
\hline 2 & 0.01 & - & & - & & - & & + & 5.35 & + & 4.03 & + & 4.9 & + & 3.58 & + & 5.05 \\
\hline 3 & 0.03 & - & & - & & + & 18.61 & - & & + & 5.24 & - & & + & 3.72 & + & 4.12 \\
\hline 4 & 0.04 & + & 7.27 & + & 9.27 & - & & + & 9.66 & - & & + & 5.9 & - & & - & \\
\hline 5 & 0.06 & + & 6.37 & + & 12.62 & - & & - & & - & & - & & - & & + & 6.97 \\
\hline 6 & 0.07 & - & & - & & - & & - & & + & 8.76 & + & 15.26 & - & & - & \\
\hline 7 & 0.08 & - & & - & & - & & + & 25.44 & - & & - & & + & 31.05 & - & \\
\hline 8 & 0.09 & - & & - & & - & & - & & - & & - & & - & & + & 16.91 \\
\hline 9 & 0.15 & + & 20.56 & - & & + & 16.92 & - & & + & 12.31 & - & & - & & - & \\
\hline 10 & 0.16 & - & & + & 13.71 & - & & - & & - & & + & $! 0.01$ & - & & - & \\
\hline 11 & 0.27 & + & 40.66 & + & 36.16 & - & & - & & - & & + & 34.73 & - & & + & 34 \\
\hline 12 & 0.28 & - & & - & & + & 40.61 & + & 37.29 & + & 40.86 & - & & + & 34.97 & - & \\
\hline 13 & 0.34 & + & 25.15 & + & 24.56 & - & & - & & - & & - & & - & & - & \\
\hline 14 & 0.35 & - & & - & & - & & + & 22.27 & - & & + & 19.46 & - & & + & 15.39 \\
\hline 15 & 0.37 & - & & - & & + & 23.87 & - & & + & 19.01 & - & & + & 12.07 & - & \\
\hline 16 & 0.53 & - & & - & & - & & - & & - & & + & 9.73 & - & & - & \\
\hline 17 & 0.55 & - & & - & & - & & - & & - & & - & & - & & + & 17.57 \\
\hline 18 & 0.56 & - & & - & & - & & - & & + & 9.8 & - & & + & 14.61 & - & \\
\hline
\end{tabular}

$(+)=$ Present band

$(-)=$ Absent band 
Five, four, seven and six esterase bands in untreated, $P$. sativum, C. sativum and $C$. citratus treated samples respectively, show activity towards $\alpha$-naphthyl acetate as shown in Figure (1).
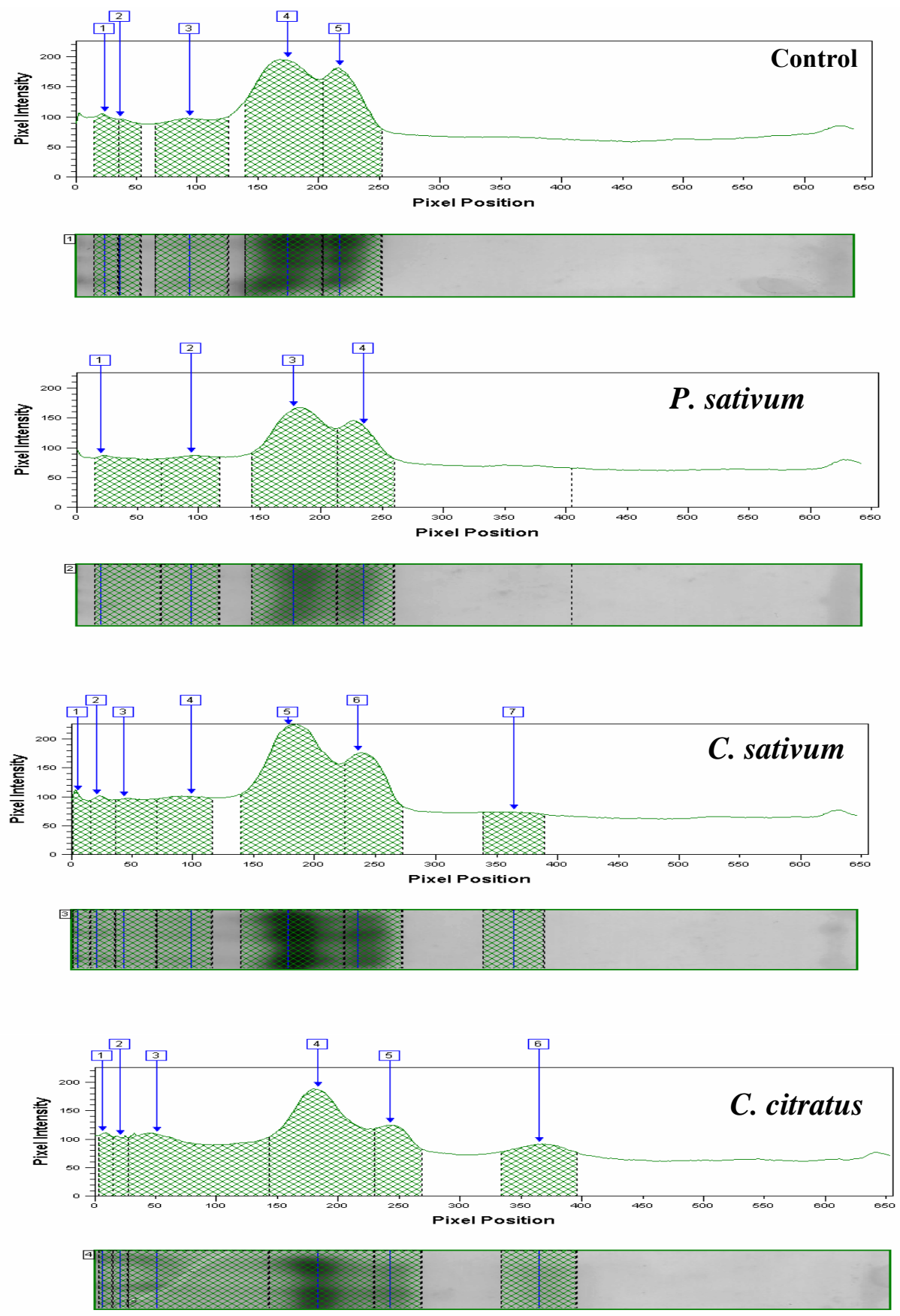

Fig. (1): Graph illustration of larval tissue esterases pattern of P. gossypiella after treated the newly hatched larvae with the tested compounds deteced by $\alpha$-naphthyl acetat as a substrate.

Six, five, seven and seven esterases were able to hydrolyze $\beta$ - naphthyl acetate in previous arrangement Figure (2).

Among these bands, the bands no. 1 and 13 were characteristic bands for control with $R_{\mathbf{f}}$ values 0.001 and 0.34 respectively, Also the bands no. 6 and 16 
appeared only in C. sativum samples with $R_{\mathbf{f}} 0.07$ and 0.53 . The bands no. 8 and 17 were characteristic for $C$. citratus samples with $R_{\mathbf{f}} 0.09$ and 0.55 respectively.

On the other hand, four common bands appeared in all treated samples. These bands are no. $3,12,14$ and 15 with $R_{\mathbf{f}} 0.03,0.28,0.35$ and 0.37 respectively.

Densitometric scanning of electrophorogram of general esterase pattern revealed that the last two bands in all samples had higher densities than others except in the case of C. sativum and C. citratus samples as shown in Table ( 2 ) and Figures (1\&2).
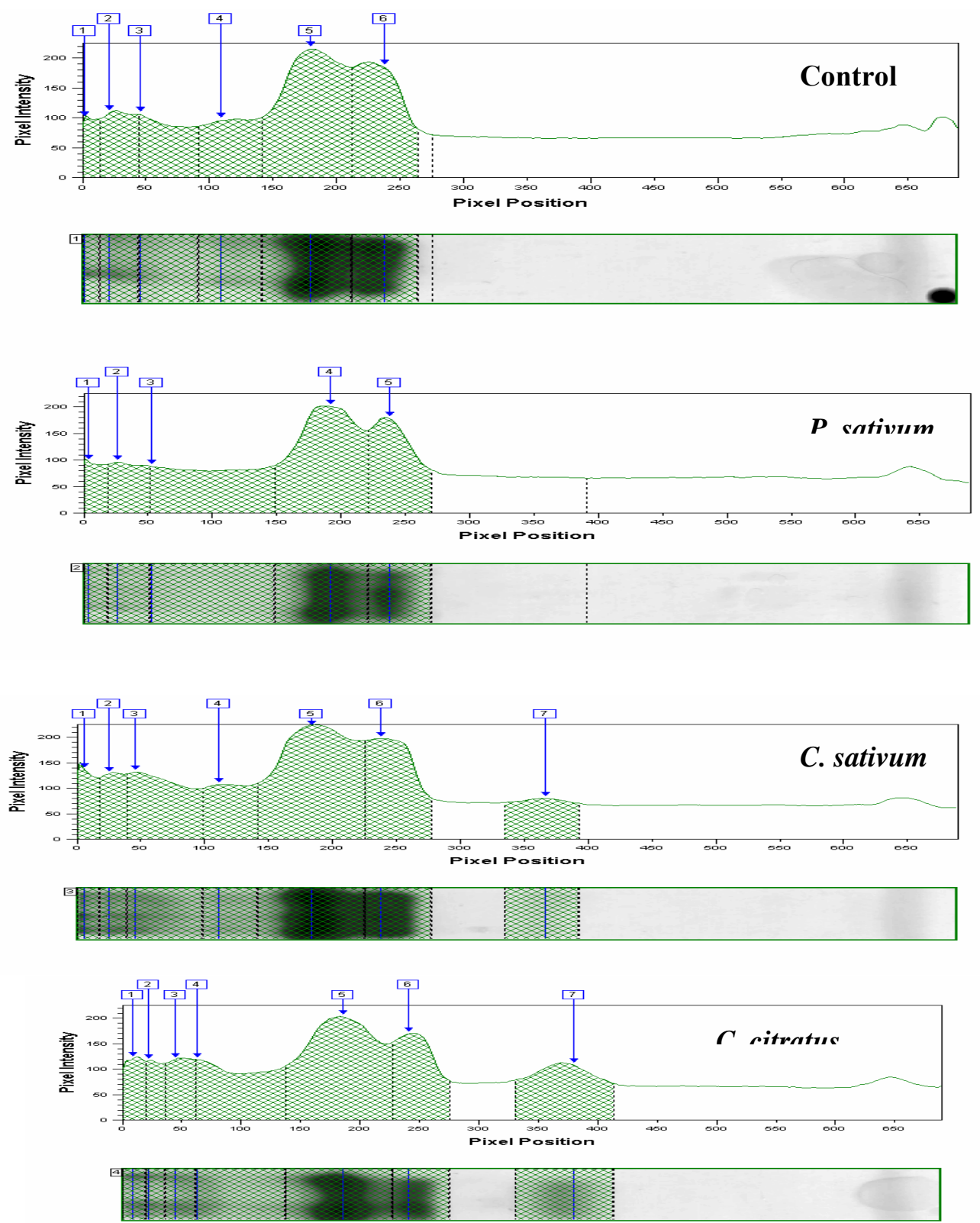

Fig. (2): Graph illustration of larval tissue esterases pattern of $P$. gossypiella after treated the newly hatched larvae with the tested compounds deteced by $\beta$ - naphthyl acetat as a substrate.

The classification of non- specific esterases is the principal aim of the inhibition studies. Bands inhibited by organophosphorus (Chlorphrifos and Fenitrothion) and carbamate (Eserine) compounds were classified as cholinesterases, 
those inhibited by organophosphorus alone were grouped as carboxyestrases and those not inhibited by organophosphorus or carbamate compounds were classified as arylesterases as clear in Table (1).

It is quite clear from results in Table (3) and plates $(1 \& 2)$ that the use of inhibitors mentioned previously revealed dominant cholinesterase activity of untreated $P$. gossypiella larvae, the $\mathrm{R}_{\mathbf{f}}$ values were $0.15,0.16,0.27$ and 0.34 , while carboxyestrase identified in two bands had $R_{\mathbf{f}}$ values 0.001 and 0.04 . Only one band with $\mathrm{R}_{\mathrm{f}} 0.06$ recorded as arylesterase.

Table (3): Response of non-specific esterase bands to specific inhibitors in larval tissues of $P$. gossypiella using $\alpha \& \beta$-naphthyl acetate.

\begin{tabular}{|c|c|c|c|c|c|c|c|c|c|c|c|c|c|c|c|c|c|c|c|c|c|c|c|c|c|c|}
\hline \multirow{3}{*}{$\begin{array}{r}\text { Band } \\
\text { No. }\end{array}$} & \multirow{3}{*}{ RF Sample } & \multicolumn{6}{|c|}{ Control } & \multicolumn{6}{|c|}{ P. sativum } & \multicolumn{6}{|c|}{ C. sativum } & \multicolumn{6}{|c|}{ C. citratus } & \multirow{3}{*}{ Type of enzyme } \\
\hline & & \multicolumn{2}{|c|}{ Es. } & \multicolumn{2}{|c|}{ Ch. } & \multicolumn{2}{|c|}{ Fen. } & \multicolumn{2}{|c|}{ Es. } & \multicolumn{2}{|c|}{ Ch. } & \multicolumn{2}{|c|}{ Fen. } & \multicolumn{2}{|c|}{ Es. } & \multicolumn{2}{|c|}{ Ch. } & \multicolumn{2}{|c|}{ Fen. } & \multicolumn{2}{|c|}{ Es. } & \multicolumn{2}{|c|}{ Ch. } & \multicolumn{2}{|c|}{ Fen. } & \\
\hline & & $\alpha$ & $\beta$ & $\alpha$ & $\beta$ & $\alpha$ & $\beta$ & $\boldsymbol{\alpha}$ & $\beta$ & $\alpha$ & $\beta$ & $\alpha$ & $\boldsymbol{\beta}$ & $\alpha$ & $\beta$ & $\alpha$ & $\beta$ & $\alpha$ & $\beta$ & $\alpha$ & $\beta$ & $\alpha$ & $\beta$ & $\alpha$ & $\beta$ & \\
\hline 1 & 0.001 & & - & & + & & + & & & & & & & & & & & & & & & & & & & Carboxyestrases \\
\hline 2 & 0.01 & & & & & & & & - & & - & & - & - & - & - & - & - & - & - & - & - & - & - & - & Arylesterases \\
\hline 3 & 0.03 & & & & & & & - & & - & & - & & - & & - & & - & & - & - & - & - & - & - & Arylesterases \\
\hline 4 & 0.04 & - & - & + & ++ & + & + & & - & & + & & + & & - & & + & & + & & & & & & & Carboxyestrases \\
\hline 5 & 0.06 & - & - & - & - & - & - & & & & & & & & & & & & & & - & & - & & - & Arylesterases \\
\hline 6 & 0.07 & & & & & & & & & & & & & - & - & - & - & - & - & & & & & & & Arylesterases \\
\hline 7 & 0.08 & & & & & & & & + & & + & & + & & & & & & & + & & + & & + & & Cholinesterases \\
\hline 8 & 0.09 & & & & & & & & & & & & & & & & & & & & - & & - & & - & Arylesterases \\
\hline 9 & 0.15 & ++ & & ++ & & + & & + & & + & & ++ & & + & & + & & + & & & & & & & & Cholinesterases \\
\hline 10 & 0.16 & & ++ & & ++ & & ++ & & & & & & & & + & & ++ & & ++ & & & & & & & Cholinesterases \\
\hline 11 & 0.27 & + & ++ & ++ & ++ & ++ & ++ & & & & & & & & ++ & & + & & ++ & & ++ & & ++ & & ++ & Cholinesterases \\
\hline 12 & 0.28 & & & & & & & + & ++ & ++ & ++ & ++ & ++ & + & & + & & ++ & & + & & ++ & & ++ & & Cholinesterases \\
\hline 13 & 0.34 & + & + & - & - & ++ & ++ & & & & & & & & & & & & & & & & & & & Cholinesterases \\
\hline 14 & 0.35 & & & & & & & & ++ & & + & & ++ & & ++ & & + & & ++ & & + & & + & & ++ & Cholinesterases \\
\hline 15 & 0.37 & & & & & & & - & & ++ & & ++ & & - & & ++ & & ++ & & - & & + & & + & & Carboxyestrases \\
\hline 16 & 0.53 & & & & & & & & & & & & & & - & & + & & ++ & & & & & & & Carboryestrases \\
\hline 17 & 0.55 & & & & & & & & & & & & & & & & & & & & - & & - & & - & Mry Lesterases" \\
\hline 18 & 0.56 & & & & & & & & & & & & & - & & + & & ++ & & - & & + & & + & & Carboxyestrases \\
\hline
\end{tabular}

Es. $=$ Eserine $\quad$ Ch. $=$ Chlorphrifos $\quad$ Fen. $=$ Fenitrothion $\quad$ Bands detected by $\alpha$-naphthyl acetate only.

$(-)$ = Non Inhibition $(+)=$ Partial inhibition $(++)=$ complete inhibition Bands detected by $\beta$-naphthyl acetate only.

Bands number $(2,3) ;(2,3,6)$ and $(2,3,5,9,17)$ in treated samples with $P$. sativum, $C$. sativum and $C$. citratus respectively were highly capable for hydrolyzing $\alpha$-naphthyl acetat and $\beta$ - naphthyl acetate after the inhibition with eserine, chlorphrifos and fenitrrothion so they classified as arylesterase. In addition, bands number $(4,15) ;(4,15,16,18)$ and $(15,18)$ were identified as carboxyestrase. While bands number $(7,9,12,14) ;(9,10,11,12,14)$ and $(7,11,12,14)$ at the previous arrangement of samples were inhibited by eserine, chlorphrifos and fenitrrothion they were classified as cholinesterase.

\section{DISCUSSION}

Esterases can often be separated into isozymes with different substrate specificities. Insect esterases are very diverse and can include monomer, dimers and multimers, which means that their relative molecular mass can cover a wide range Dauterman, (1985). Therefore electrophoresis plays a major role in identifying esterases Grafton-Cardwell et al., (1998).

In the present work, polyacrylamide gel electrophoresis was used for separation of different isozymes. Esterases in $P$. gossypiella larvae showed greatest specific activity toward $\alpha$-naphthyl acetate and $\beta$ - naphthyl acetate. These results are 
agreement with many authors, El-Bermawy, (2000) on Bombyx mori and Spodoptera littoralis.

El-Deeb et al., (2002) observed that the optimum substrate of Earias insulana larvae were either $\alpha$-naphthyl acetate or $\beta$ - naphthyl acetate depending on the type of tissues. In addition, the results were showed great differences in number of zones of esterase activity and in substrate specificity between treated and untreated samples. Similar results were observed by El-Bermawy, (2004) who analyzed esterases from body extracts of $6^{\text {th }}$ larval instar and newly formed pupa of $S$. littoralis produced from treated $2^{\text {nd }}$ larval instar by four plant extracts using polyacrylamide gel electrophoresis and two substrates.

Esterases have routinely been classified according to their reaction with various specific enzyme inhibitors Bush et al., (1970). At least three classes of esterases can be identified based on the substrate specificity and the inhibition tests of Augustinsson, (1961) The current research discussed the usage of three inhibitors (eserine, chlorphrifos and fenitrrothion) with $\alpha$-naphthyl acetate and $\beta$ - naphthyl acetate as substrates to identify the band detected in untreated and treated samples of the last larval instar of P. gossypiella.

In the case of $\alpha$ - naphthyl acetate as substrate, all volatile oils caused the increasing of arylestrases and carboxylestrases activities, while cholinesterase activity was inhibited. Shakoori et al., (1994) mentioned that the sublethal dose $\mathrm{LC}_{50}$ of Cypermethrin increased carboxylestrases activities (54\%) and decreased the cholinesterase activities (65\%) in Tribolium castaneum larvae. However, Cruz et al., (1997) strengthen the hypothesis that the mechanism associated with insecticides resistance found in many insects includes an increase of esterase activity, propaply as a result of gene amplification.

In general, the importance of esterases in physiology, metabolism and detoxification of xenobiotics in insects was concluded by Davis et al., (1995); Sivakumarm \& Maya, (1991) and Shen \& Dowd, (1991).

Acetylcholine esterase (AchE) has the potential for serving as a biochemical indicator of toxic stress. So AchE activity has the potential to serve as a biomarker of heavy metal pollution [Hama, (1976) and Gerson et al., (1991)].

Carboxylesterases are closely related to cholinesterase, since they hydrolyze a wide range of aliphatic ester including cholinesterase. Also, Carboxylesterases isozymes are more responsible for insecticides resistance than other esterase isozymes Raymond et al., (1987); Wirth et al., (1991) and Xuguo et al., (2005).

Arylesterases readily hydrolyze a variety of aromatic esters, but have little action with aliphatic esters. Zhukausken et al., (1983) mentioned that the synthesis of arylesterases in haemolymph of Galleria mellonella larvae bloked B. thuriengensis infection indicating a direct relationship between these isozymes and the immunological properties of insects.

Finally, it can be concluded that the over production of carboxyesterases and arylesterases as a response to the treatment with $\mathrm{LC}_{50}$ of three volatile oils (Petroselinum sativum, Coriandrum sativum and Cymbapoyon citratus) may explain the ability of this insect to secret a high concentration of esterase to minimize the effect of these compounds as apart of defense mechanism. On the other hand, the Inhibition of cholinsesterase revealed that these compounds may be affected the central nervous system of the treated insect. 


\section{REFERANCES}

Abd-El-Hafez, A.; Metwally, A. G. and Saleh, M. R. A. (1982). Rearing Pink bollworm Pectinophora gossypiella (Saunders) on kidney bean diet in Egypt. Res. Bull, Faculty of Agric., Zagazig University, April, No. 576, 10 pp.

Augustinsson, K.B. (1961). Multiple forms of esterases in vertebrate blood plasma. Ann. N.Y. Acad. Sci., 94: 844-860

Bush, F. M.; Price, J. R. and Towsend, J. I. (1970). Plasma esterases. thier definition and status as isozymes in the house sparrow. Int. J. Biochem., 1:85-107

Cruz, R.R.; Miranda, E.M.; Vasquez, Z.G. and Estrada, M.D. (1997). Detection of esterase activity in susceptible and organophosphate resistant strains of the cattle tick Boophilus microplus ( Acari : Ixodidae). Bull. Entomol. Res. 87:197-202.

Dauterman, W. C. (1985). Insect metabolism: extramicrosomal, pp; 713-730. Inkerkut, G. A. and Gilbert, L. I (eds.), comprehensivc insect physiology.

Davis, R. w.; Kamble, S. T. and Prabhakaran, S. T. (1995). Characterization of general esterases in workersd of eastern subterranean termite (Isoptera:Rhinotermitidae). J. Econ. Entomol., 88 (3): 574-478.

Devonshire, A. L. (1991). Role of esterases in resistance of insects to insecticidesBiochem Soc - Trans., 19: 755-759.

EL-Bermawy, S.M. (2000). Esterase pattern comparison of six stages from Bombyx mori and Spodoptera littoralis. J. Egypt. Ger. Soc. ZooL., vol. 32(E) Entomology, 5-74.

EL-Bermawy, S.M. (2004). Esterase patterns in Spodoptera littoralis(Boisd) after botanical extract treatments. J.Egypt. Ger. Soc.zool. vol (43A): comparative physiology 119-136.

EL-Deeb, W. M.; Salama, M.S.; Zidan, Z. H.; Abdel-Rahman, H.A. and Radwan, E.M. (2002). Patterns and activities of estrases of the spiny bollworm as affected by insecticides. (2002) the first conf. Of the contral Agric. Pesticide Lab., 514-527.

Grafton- Cardwell, E.; Ouyang, Y. and Salse, J. (1998). Insecticide resistance and esterase enzyme variation in the California Red Scale (Homoptera: Diaspidae). J. Econ. Entomol., 91(4): 812-819.

Gerson, U.; Mozea-Koch, R. and Cohen. E.(1991). Enzyme levels used to monitor pesticide resistance in Varroa jacbsoni. J. Agricultural Res, 30 (1): 17-20.

Hama, H. (1976). Modified and normal cholinesterases in the respective strain of carbamate resistant and susceptible green rice leaf hopper, Nephottatix cincticeps (Uhler) Hemiptera: Cicadellidae). Appl. Entomol. Zool., 11: 239-247.

Kojima, K.; Gillespie, J. and Tobbari, X.N. (1970). A Profile of Drosophila species enzymes assayed by electrophoresis. 1. Number of alleles, heterozygosites and linkage disequilibrium in glucose metabolizing system and some other enzymes. Biochem. Genet., 4; 627-637.

Raymond. M.; Pasteur, N.; Georghiou, G.P.; Melon, R. B.; Wirth, M.C. and Hawley. M. (1987). Detoxification esterases new to California in organophosphate resistance Culex quinquefasiatus (Diptera: Culicidae). J. Med. Entomol., 24: 24-27. 
Salama, M. S.; Schouset, L.P. and Miller, T. A. (1992). Effect of diet on the esterase patterns in the hemolymph of the corn earworm and tobacco budworm (Lepidoptera: Noctuidae). J. Econ. Entomol., 85 (4): 1079-1087.

Shakoori, A.R.; Sadia, D.; Saleem, M.A. and Durrani, S. (1994). Sublethal effects of a synthetic pyrethroid, Ripcord 10 EC, on Tribolium castaneum. Proc. Pakistan. Cong. Zool. 14: 351-360.

Sell, D. K.; Whitt, G. S.; Metcalf, R. L. and Kanlee, L. P. (1974). Enzyme polymorphism in corn ear worm Heliothis zea (Lepidoptera: Noctuidae) Hemolymph esterase polymorphism. Can. Ent., 106 : 701-709

Shen, S.K. and Dowd, P. F. (1991). 1-Naphthyl acetate esterase activity from cultures of the symbiont yeast of cigarette beetle (coleopteran: Anobiidae) J. Econ. Entomol., 84: 402- 407.

Sims, M. (1965). Methods for detection of enzymatic activity after electrophoresis on polyacrylamide gel in Drosophila species. Nature, Lond., 207: 757-758.

Sivakumarm, S. and Maya, Z. B, (1991). Electrophoretic characterization of esterase in the greenbug, Schizaphis germanium. J. Kans. Entomol. Soc., 64: 357-362.

Wirth, M. C.; Marquine, M.; Georghiou, G.P. and Pasteur, N. (1991). Esterases $\mathrm{A}_{2}$ and $\mathrm{B}_{2}$ in Culex quinquefasiatus (Diptera: Culicidae): Role in organophosphate resistance and linkage. J. Md. Entomol., 27: 202-206.

Xuguo,Z; Michael, F. S.; Lance, J.M.; Laurence, D. C.; and Blair D. S.(2005). Immunological assessment of an insecticide resistance - Associated Esterase in the western corn rootworm. Arch. Insect Biochem. Physiol. 58: 157-165.

Zhukausken, Y. I.; Zayanchkauskas, P. A.; Struoga, A. A. and Shirvinskas, Y. M. (1983). Esterases of the larval haemolymph of the greater wax moth Galleria mellonella during the late instar. Vilnius, USSR, Vsesoyunzoe Entomolog: Cheskoe obshchestvo: 80-84. Rev. Appl. Entomol., A, 72:77. 
Plate [1 $(\alpha-n)]$ Esterases pattern of larval tissue of P. gossypiella after treated the newly hatched larvae with the tested compounds deteced by $\alpha$-naphthyl acetat as a substrate.

Plate [1 (Es.)] An electophotograph of larval tissue esterases of P. gossypiella gave positive enzymatic reaction with $\alpha$-naphthyl acetat after inhibition with eserine.

Plate [1 (ch.)] An electophotograph of larval tissue esterases of P. gossypiella gave positive enzymatic reaction with $\alpha$-naphthyl acetat after inhibition with Chlorphrifos.

Plate [1 (Fen.)] An electophotograph of larval tissue esterases of P. gossypiella gave positive enzymatic reaction with $\alpha$-naphthyl acetat after inhibition with Fenitrrothion.

Plate [2 $(\beta-n)]$ Esterases pattern of larval tissue of $P$. gossypiella after treated the newly hatched larvae with the tested compounds deteced by $\beta$-naphthyl acetat as a substrate.

Plate [2 (Es.)] An electophotograph P. gossypiella esterases gave positive enzymatic reaction with $\beta$-naphthyl acetat after inhibition with eserine.

Plate [2 (Ch.)] An electophotograph P. gossypiella esterases gave positive enzymatic reaction with $\beta$-naphthyl acetat after inhibition with Chlorphrifos.

Plate [2 (Fen.)] An electophotograph P. gossypiella esterases gave positive enzymatic reaction with $\beta$-naphthyl acetat after inhibition with Fenitrrothion.

A = Larval tissue samples of Control

$\mathbf{B}=$ Larval tissue samples of $P$. sativum oil

$\mathbf{C}=$ Larval tissue samples of C. sativum oil

$\mathbf{D}=$ Larval tissue samples of C. citratus oil

$\alpha-n=$ esterase pattern by $\alpha-$ naphthyl acetate

$\beta-\mathrm{n}=$ esterase pattern by $\beta$ - naphthyl acetate

Es. $=$ Eserine

Ch. $=$ Chlorphrifos

Fen. $=$ Fenitrothion 


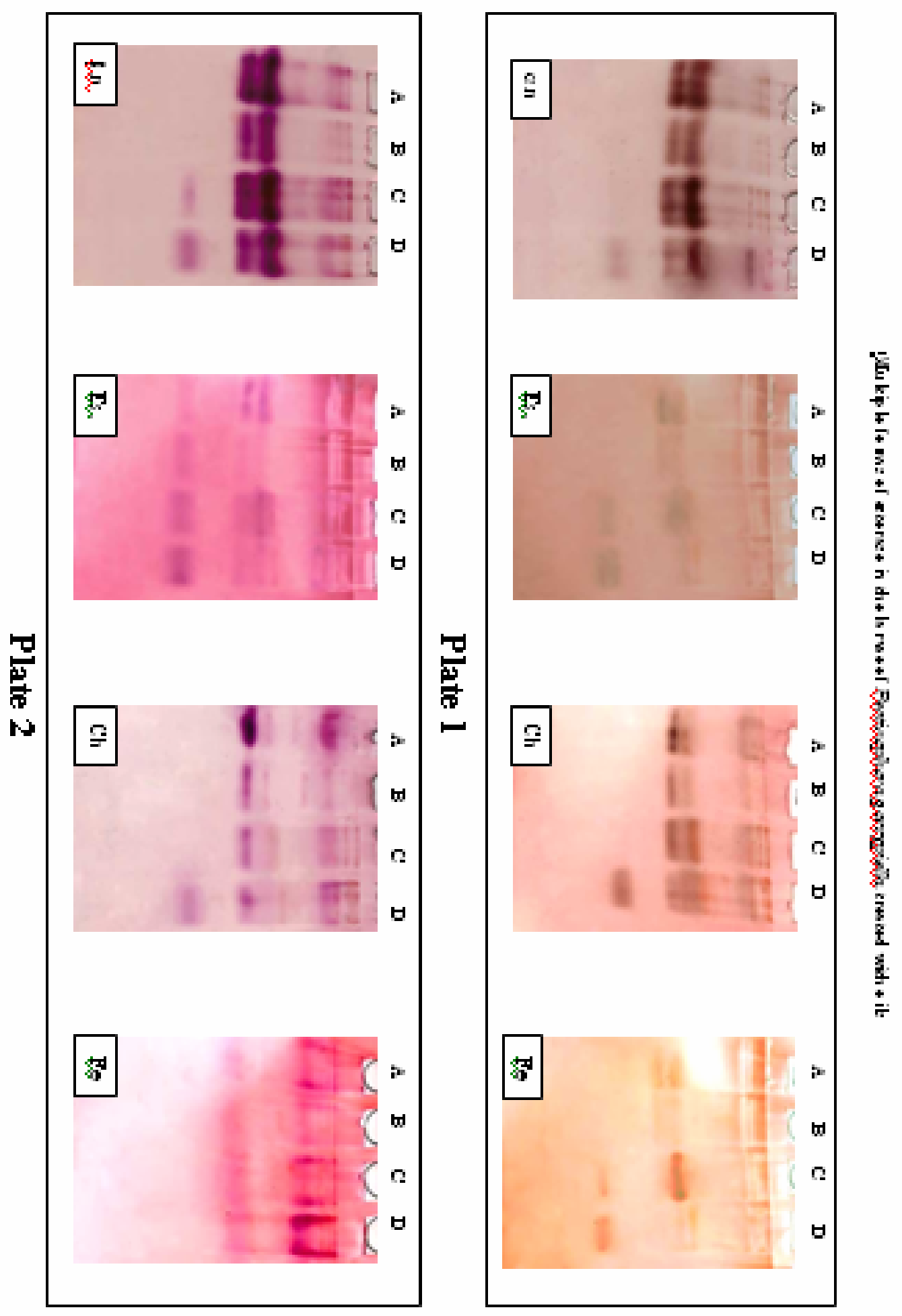




\section{ARABIC SUMMERY}

\section{الأنماط المتعددة لانزيم الاستيريزفى يرقات دودة اللوز القرنقلية المعاملة بثلاثة انواع من الزيوت

$$
\text { الطيارة. }
$$

$$
\begin{aligned}
& \text { هبة عبد الوهاب حسن - سندس عبد التواب محمد إبدا } \\
& \text { معهد بحوث وقاية النباتاتــ مركز البحوث الزر اعية ـ الدقىـ جيزة. }
\end{aligned}
$$

لقد تم در اسة الانماط المتعددة لانزيم الاستيريز فى الطور اليرقى الاخير لدودة اللوز القرنفلية

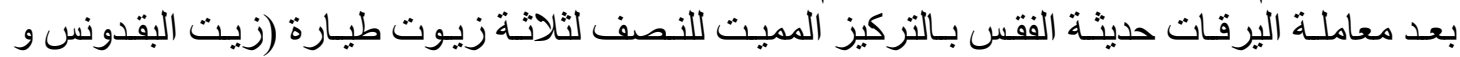

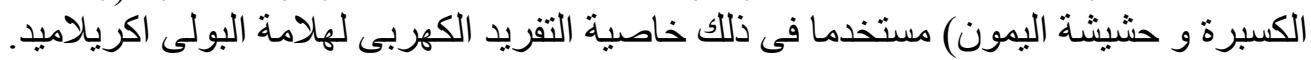

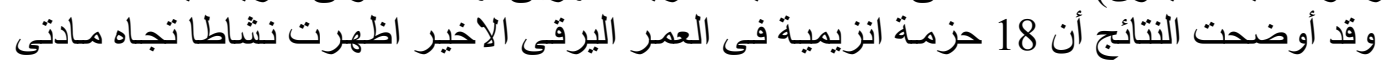

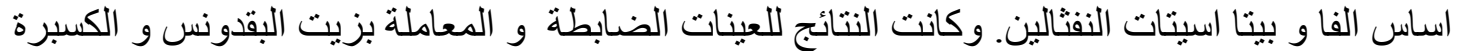

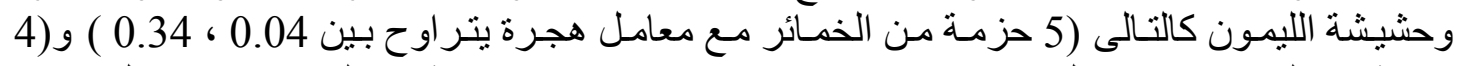

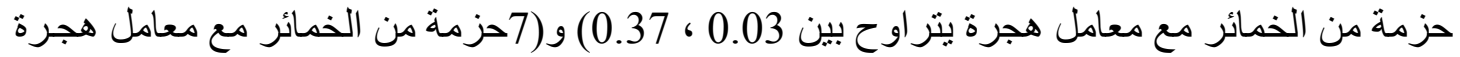

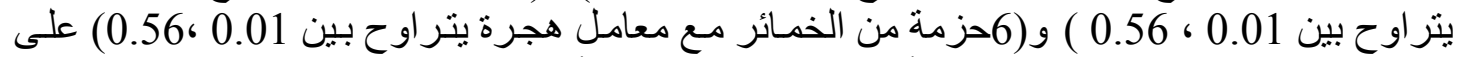

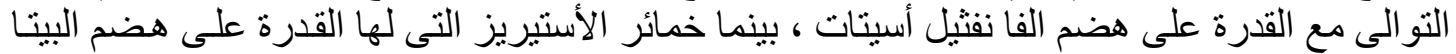

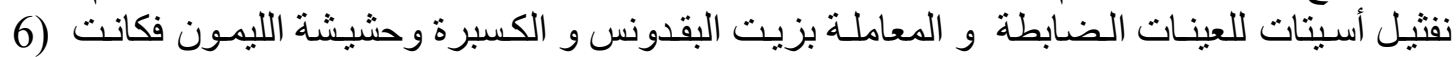

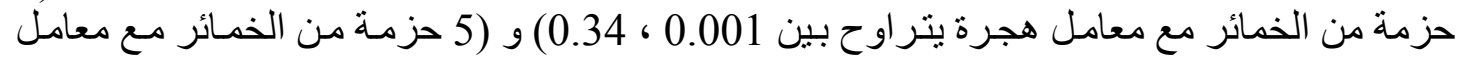

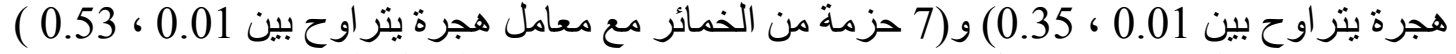

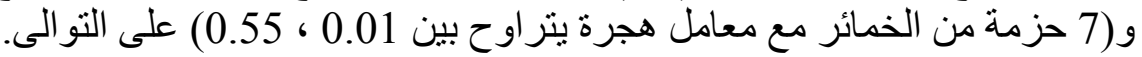

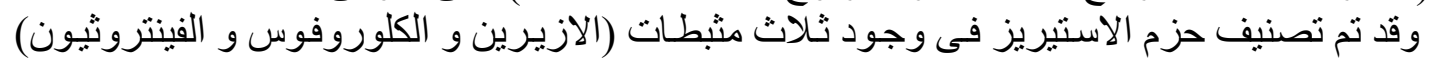

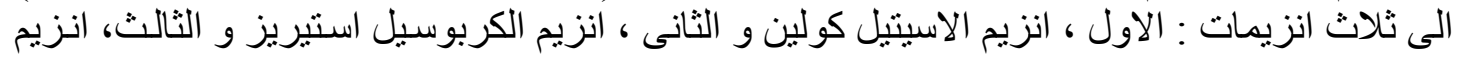

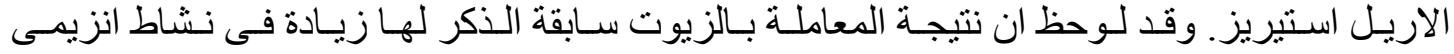
الكربوكسيل استيريز و الاريل استيريز مع تاثير تثبيطى لانزيم الكولين استيريز. 